\title{
Un cuchillo en el corazón. \\ Gaspar Noé: ¿cineasta de un social contemporáneo? La tragedia de un hombre (solo) en la tragedia del siglo.
}

\author{
Solo contra todos | Gaspar Noé | 1998 \\ Vladimir Broda* \\ Paris 1 Panthéon-Sorbonne UFR04
}

Recepción: 15 de diciembre de 2019; aceptación: 2 de febrero de 2020

\begin{abstract}
Resumen
“¿Cuáles son los límites del tratamiento cinematográfico de la “moral” y la “justicia”? El film de Gaspar Noé "Solo contra todos” tiene la virtud de poner a prueba nuestra capacidad de tolerancia a la emergencia de lo real. ¿Es la violencia de los traumas originales (masacre del padre y abandono de la madre) reparable, o está condenada a repetirse de generación en generación? Las definiciones de moralidad y justicia se ven conmovidas a lo largo de esta película, enmarcada en el corazón de una tragedia histórico-social: la ley simbólica no hace más ley. En estas coordenadas, ¿no está el sujeto condenado a transgredir, incluso en un rescate del “amor”, la ley simbólica de la prohibición del incesto?”
\end{abstract}

Palabras clave: Tragedia Social | Moral | Justicia | Simbólico | Amor | Soledad

A knife is born at the heart. Gaspar Noé: filmmaker of a contemporary social? The tragedy of a man (alone) in the tragedy of the century.

Abstract

What are the limits of the cinematographic treatment of "morals “ and "justice”? Gaspar Noé's film " Alone Against All” has the virtue of testing our capacity to tolerate the emergence of the real. Is it the violence of the original traumas (slaughter of the father and abandonment of the mother) repairable, or is it condemned to be repeated from generation to generation? The definitions of morality and justice are moved throughout this film, framed in the heart of a historical-social tragedy: the symbolic law makes no more law. In these coordinates, is not the subject condemned to transgress, even in a rescue of "love", the symbolic law of the prohibition of incest? "

Keywords: Social tragedy | morals | justice | symbolic | love | loneliness

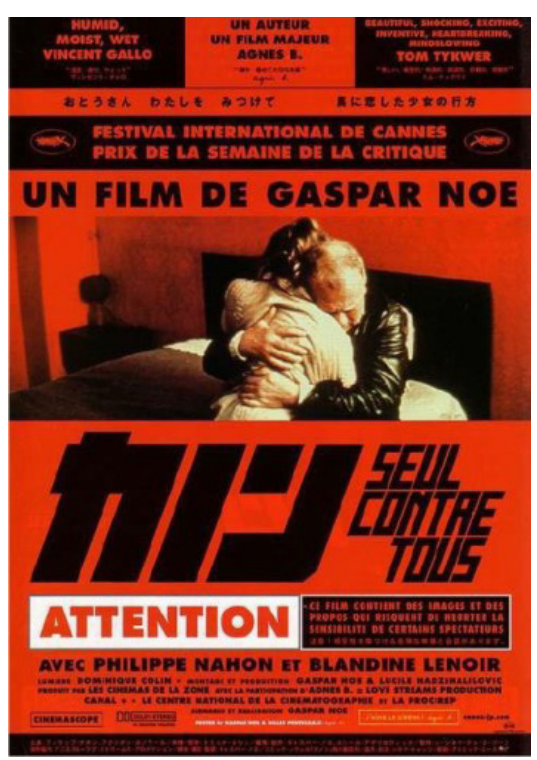

«"El miedo en sus ojos y el cuchillo en el pecho". La angustia del miedo [Angst], Gerald Kargl, 1983.

Antes de entrar en el meollo del tema, resulta importante hacer un repaso de la biografía de Gaspar Noé. En efecto, su vida privada guarda cierta conexión con la del protagonista de Solo contra todos, su primer largometraje, realizado en 1998. Noé nació en 1963 en Buenos Aires, Argentina, en el seno de una familia políticamente comprometida, y proviene de un ámbito intelectual y artístico. Se instaló en Francia con sus padres, exiliados políticos, en 1976, tras el comienzo del golpe de Estado que se llamó "Proceso de reorganización nacional".

Esta investigación aborda el análisis de Solo contra todos, película de Gaspar Noé de 1998. Una tragedia in-

* michelebenhaim3@gmail.com 
dividual cruza una tragedia social a través del "drama de un excarnicero que se debate solo en las entrañas de su país". Su país es la Francia de los años ochenta, gris, racista y deteriorada.

Ronald Reagan en Estados Unidos, Margaret Thatcher en Gran Bretaña, François Mitterand en Francia (cuyo mandato vaciló entre la reactivación económica y la recesión) marcan el estilo de esos años. Se produce una ofensiva liberal que rompe con los años sesenta y setenta. Se observa el aumento del desempleo, la retirada del Estado, el cuestionamiento de los servicios públicos y de las políticas sociales; se anuncian los años "ochenta/dos mil”: la globalización y la financiarización de la economía.

Francia pierde 670.000 puestos de trabajo en el sector industrial entre 1982 y 1990. La desindustrialización tiene consecuencias dramáticas para el mundo obrero, como el desempleo y la desafiliación. A eso, se agrega una "crisis del sindicalismo". En el plano político, surge el Front National. ${ }^{1}$ Después de 1983 y el inicio del rigor, la izquierda vuelve a dividirse, se trata de un fracaso estrepitoso. El Partido Comunista pierde su influencia. Sin embargo, hay luchas emblemáticas como las de los años 1986-1987: un mes de huelga de la SNCF. ${ }^{2}$ En el mismo período, los estudiantes logran que se retire la ley Devaquet. $^{3}$

"Esta historia comienza en Francia, en pleno centro del desastre, en el país del queso y de los colaboracionistas", esas son las primeras palabras del Carnicero, acompañadas de una fotografía de Adolf Hitler y del mariscal Philippe Pétain estrechándose la mano.

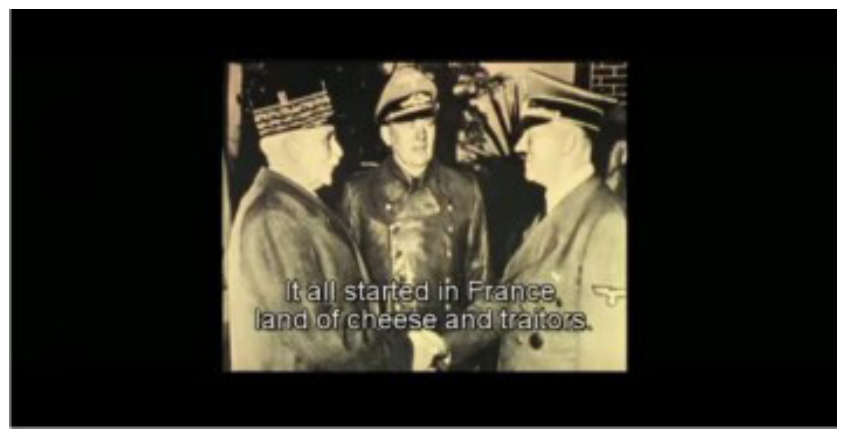

Una de las numerosas diapositivas de la primera secuencia de Solo contra todos, en la que se muestra una fotografía de Hitler y Pétain, Noé

Durante los años ochenta, el negacionismo hace su "gran" entrada. Robert Faurisson comienza a hacerse ampliamente conocido por sus tesis negacionistas, y Jean-Marie Le Pen declara en una importante radio pública, en 1987, que él "no ha estudiado especialmente el tema, pero cree que es un detalle de la bistoria de la Segunda Guerra Mundial", al hablar de las cámaras de gas. El negacionismo provocador y creciente de esa época va de la mano con la persecución de los antiguos nazis de alto rango (por ejemplo, Klaus Barbie), algunos de los cuales ni siquiera se habían tomado la molestia de ocultarse y seguían teniendo responsabilidades importantes (como Maurice Papon, excolaboracionista y luego ministro, o Kurt Waldheim, secretario general de Naciones Unidas de 1972 a 1981 y presidente federal de la República de Austria de 1986 a 1992).

En la noche del 5 al 6 de diciembre de 1986, en la calle Monsieur-le-Prince, un joven estudiante de 22 años, Malik Oussekine, es víctima de una golpiza por parte de la policía francesa de Charles Pasqua. Morirá.

Tras esta breve introducción histórica, nos corresponde situar Solo contra todos en la obra de Gaspar Noé. Obra maestra subversiva para algunos, abominación perversa y sádica para otros, Solo contra todos (y las películas de Noé en general) no nos decepciona. Solo contra todos, extensión del mediometraje realizado ocho años antes, Carne (1991), se sitúa al principio de la obra de Noé y es completamente diferente de sus trabajos futuros, a pesar de su persistente voluntad de representar lo Real (seguramente subyacente e inconsciente, sin embargo).

No obstante, Solo contra todos no es la película que "dio a conocer" a Noé a sus "detractores". Irreversible, que se estrenó en 2002, retumbó como una bomba en el cine francés, lo que le permitió a Noé adquirir el papel del rey del "vean lo que no quieren ver". En efecto, a partir del estreno de esa película, a Noé se lo consideró alguien "único" en el cine francés. Le siguió la filmación de Enter The Void (2010), proeza técnica, estética singular (gracias a la ayuda de Benoît Debie, su director de fotografía "designado"), con la que Noé nos transporta al viaje completamente psicodélico del espíritu después de la muerte; luego, vino Love (2015), película que se caracteriza sobre todo por tener escenas de sexo no simuladas, sin que la película sea pornográfica (algo que, evidentemente, suscitó polémicas con respecto a su clasificación). Tres años más tarde, Noé estrenó Climax (2018), en la que filmó una velada después del último ensayo de una compañía de bailarines, y su descenso a los infiernos tras haber ingerido involuntariamente una droga (LSD).

Carne, su mediometraje de 1991, puede considerarse el prólogo de Solo contra todos. La película debería 
haberse llamado Rance [Rancio]. Por supuesto, se trata de un anagrama de Carne, pero es también, y sobre todo, una parte de la palabra France [Francia], que El Carnicero define como "un gran camembert que apesta, con muchos gusanos que proliferan en su interior". Esa película introduce el díptico Carne/Solo contra todos, que no había sido previsto originalmente. Carne cuenta la historia de un carnicero equino, solo con su hija Cynthia tras la desaparición de la madre (posteriormente sabremos que se "tiró a las vías del subte"). Tras la llegada de la primera menstruación de Cynthia, quien, enloquecida, va a ver a su padre para entender esos cambios, este último imagina lo peor: la violación de su "bijita” por un obrero "árabe”, a quien se apresura a perseguir para clavarle un puñal en la boca. Se equivocará de obrero, la víctima sobrevivirá, Cynthia irá a un hogar y El Carnicero irá a la cárcel.

Luego, viene Solo contra todos, película en la que, en gran medida, se apoya y con la que se relaciona nuestro análisis. Fuertemente inspirado en Angst ( La angustia del miedo) de Gerald Kargl (1983), Noé retoma el mismo dispositivo que utiliza dicho director: una voz en off permanente, que revela los pensamientos del protagonista, en un mar de palabras que rara vez se interrumpe, incluso cuando el personaje de Solo contra todos (o el asesino de La angustia del miedo) no está en pantalla. Esta película trata sobre la historia de un hombre, un carnicero, El Carnicero (nunca se dice su nombre en la película, aunque en los primeros minutos aparece su documento en pantalla, que nos indica que se llama Philippe Chevalin) ${ }^{4}$; su "bistoria es muy simple, es la de un pobre tipo", según sus propias palabras. En adelante, usaremos mayúsculas cuando hablemos del Carnicero, para darle un nombre, con todo lo que eso conlleva.

Una de las particularidades de esta película es el sistema de “puntuación”, que también aparece en Carne, pero que es sistemático en Solo contra todos. Sin embargo, resulta complicado desarrollarlo y, por lo tanto, preferimos citar a Noé (2014) a modo de explicación:

"Hay dos tipos de efectos sonoros:

- Los “Bum!”, que marcan elipsis y suelen estar acompañados de un breve intertítulo negro;

- y los “iBang!” (o “;Blang!”), que acompañan los efectos de travelling en pixilación rápida realizados con cuatro o siete imágenes". (P. 54)

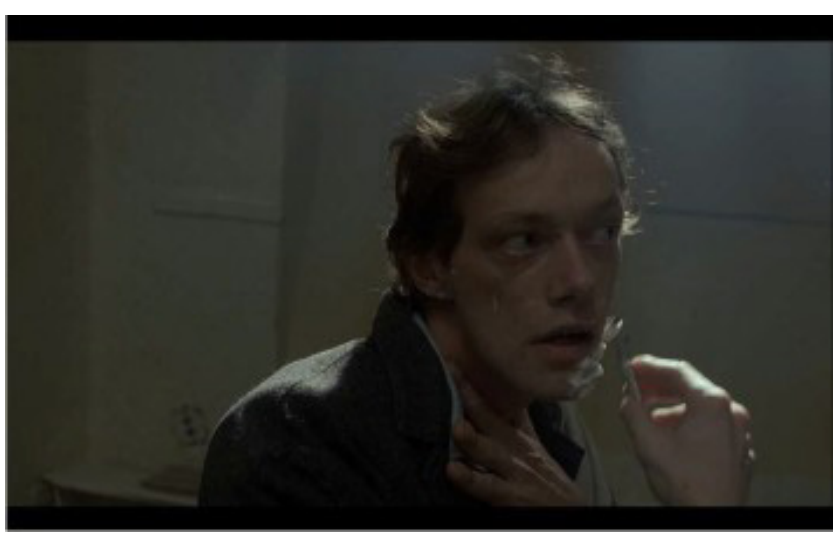

Escena de afeitado, Angst (La angustia del miedo), Kargl

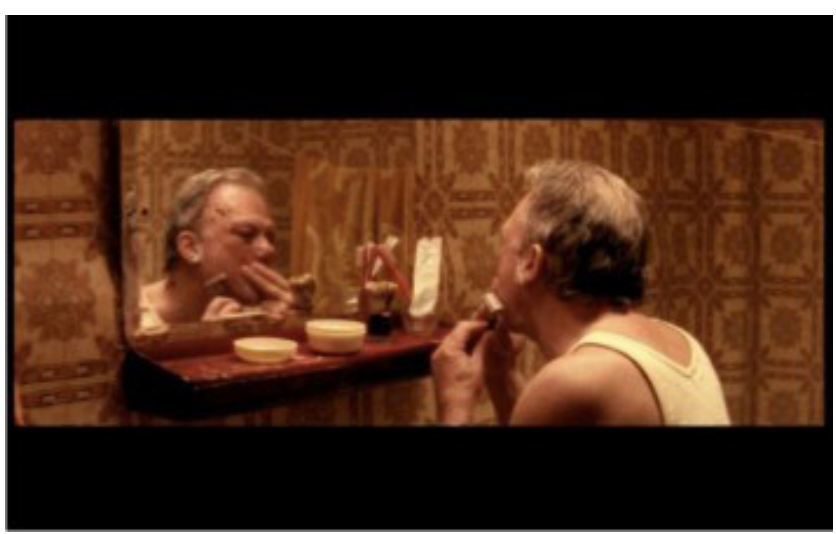

Escena de afeitado, Carne, Noé

El desafío de esta investigación es, por un lado, otorgar credibilidad a Noé, desdiabolizarlo, lograr que se reconozca su talento -tanto técnico como estético- para dirigir películas sobre temas, a priori, irrepresentables. También se trata de poner de manifiesto la dimensión paradójicamente ética de su postura que consiste, justamente, en mostrar lo inmostrable. ¿Acaso no es eso, en efecto, lo que permite la imagen en el cine? Cierta resolución de esa paradoja que, cuando el director une talento con ética, consiste en representar lo irrepresentable desde un enfoque que consiste en despertar en el espectador una pregunta, y no desde un punto de vista exhibicionista (lo que solo tendría el efecto de posicionar al espectador como un voyeur). Pero los desafíos de este tema tienen que ver, especialmente, con el tratamiento cinematográfico que puede hacerse de "la moral" y de "la justicia", puestas a prueba por las transgresiones psíquicas singulares, como el abandono materno y el incesto, así como por los sufrimientos sociales en los que estas se inscriben, particularmente la guerra, la miseria y la soledad.

Agamben (2008) define al "hombre contemporáneo" como un hombre "más apto que los demás para percibir 
y comprender su tiempo... El contemporáneo es quien observa detenidamente su tiempo para percibir en él, no las luces, sino la oscuridad... El contemporáneo es, entonces, quien sabe ver esa oscuridad" (p.10). Esa definición evoca, inevitablemente, el trabajo de Gaspar Noé. En efecto, para Agamben, es posible pertenecer a una época sin dejar de odiarla irrevocablemente (es el caso del Carnicero en Solo contra todos). Para Agamben, resulta imposible huir de la propia época. ¿A Noé lo supera su obra? Lo que nos muestra nos da más para pensar que lo que nos dice.

A través de Solo contra todos de Gaspar Noé y a través de las definiciones que el cineasta propone para la moral y la justicia a lo largo de dicha película, intentaremos mostrar que, en medio de una tragedia histórico-social, la ley simbólica ya no impone la Ley. La película de Noé intenta, en un gesto desesperado, no reconciliar el amor con la ley (condición para ocupar una posición soportable en el mundo), sino recomponer una identidad herida a lo largo de la Historia (el padre del héroe era un miembro de la resistencia comunista que murió estando deportado). ¿La violencia de los traumas originales (muerte del padre y abandono de la madre) es reparable o está destinada a repetirse de generación en generación? ¿El sujeto no está condenado a transgredir, incluso por medio de un rescate "amoroso", la ley simbólica de la prohibición del incesto? Cuando nada aparece unido en lo social, ¿solo el amor "contra todos" es pensable o posible?

\section{1. "Solo": El hombre reducido a un objeto-basura}

"El sentimiento de nuestra existencia depende, en gran parte, de la mirada de los otros sobre nosotros: por eso, podemos calificar de no humana la experiencia de quien ha vivido días en los que el hombre era un objeto ante los ojos del hombre". Primo Levi (1990).

\section{a. Soledad, errancia y abandono: la fuente de un derrumbe simbólico}

En Freud, la soledad se interpreta como un estado: un estado de soledad-desamparo, dicho de otro modo, el objeto mismo de la angustia humana; mientras que, en Mélanie Klein, la soledad se vincula con las angustias paranoides. El sujeto se siente perseguido por objetos malos, se siente solo en ausencia de un objeto bueno que lo contenga (para el cual, aquí, podemos pensar que el carnicero encuentra un substituto en el arma que porta), así como de un Otro caritativo, lo que Freud llama Nebenmensch, el ser de al lado. ${ }^{5}$

La capacidad de un ser humano para soportar la soledad depende de la posibilidad que haya tenido para interiorizar un objeto bueno, generalmente su madre. En el caso del Carnicero, la suya lo abandonó, y a esto se suma que, cuando era muy joven, su padre murió estando deportado. Ahora bien, el primer encuentro anticipa y determina los que le siguen. El Carnicero no tiene, entonces, ningún sentimiento de seguridad interna, es decir, aquel que permite ligar pulsión de vida y pulsión de muerte (aunque el arma que lleva siempre consigo pueda substituirse como objeto externo de seguridad); en El Carnicero, esas pulsiones están desligadas y la pulsión de muerte prevalece en su dimensión de pulsión destructiva.

¿Cómo logramos vivir cuando solo lo negativo nos representa ante los ojos del mundo? El Carnicero es un "sin": sin empleo, sin techo, sin familia. Arrastra su existencia como una carga imposible, con un rostro impasible y gris, una mirada fija y hostil y una palabra casi inexistente, salvo, tal vez, para engendrar odio.

Filosóficamente hablando, la soledad del Carnicero está relacionada con su experiencia de la clandestinidad. En efecto, al salir de la cárcel, El Carnicero se dirige al bar de su antigua vida, donde la patrona le ofrece trabajo, así como un intento de relación, que por supuesto fracasará lastimosamente. A raíz de esta "unión”, deciden vender el bar y mudarse a los suburbios de Lille para comprar una carnicería, con el objetivo de que la patrona pueda descansar, puesto que está embarazada. Dicho de otro modo, abandona por segunda vez a su hija adolescente, por quien antes experimentaba pulsiones incestuosas, para instalarse en las afueras de Lille con una mujer embarazada a quien detesta y la madre de esta, a quien odia aún mas ("un salamín de mierda, un vino de mierda, y una familia de mierda en un poblacho de mierda").

Finalmente, el proyecto de la nueva carnicería no se concretará, ya que, según la patrona, "era un mal negocio. Y [ella] prefiere guardar [su] dinero hasta después del parto". Mal que bien, El Carnicero encuentra un trabajo como guardia nocturno en un asilo. A pesar de ese intento de mantenerse unido a lo social, visto como un esfuerzo que parece sobrehumano para él, El Carnicero no puede sino autoexcluirse, todo le juega en contra. Cuando una 
de las pacientes del asilo muere delante de él, no reacciona, se queda inmóvil, sin compasión, sin sentimientos frente a la enfermera y, especialmente, frente a la muerte, ya que "a fin de cuentas, la muerte no es gran cosa. Se hace todo un drama al respecto, pero cuando la ves de cerca, no es nada. Es un cuerpo sin vida, nada más".

$\mathrm{Su}$ incomunicabilidad refuerza su soledad, pero "la soledad no significa nada. Da lo mismo si vivís con un tipo o una mina, o incluso con pibes, estás solo, sí. Yo estoy totalmente solo".

Aquí, la soledad se acentúa mediante procedimientos técnicos ingeniosos: la película está filmada en 16 milímetros scope, pero la imagen se amplía a 35 milímetros. Esto la deforma y genera un formato muy particular: angosto en altura y muy extendido a lo largo. Por esa razón, a veces las perspectivas y las líneas de fuga se acentúan mucho y los primeros planos son extremadamente estrechos.

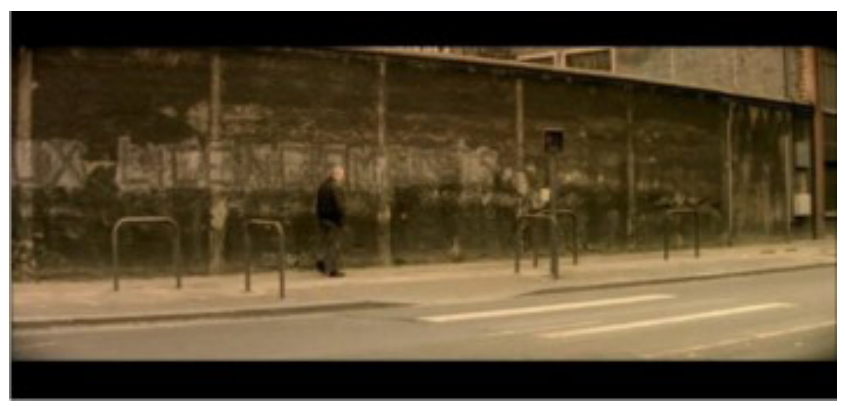

La errancia permanente y los espacios amplios, Solo contra todos, Noé

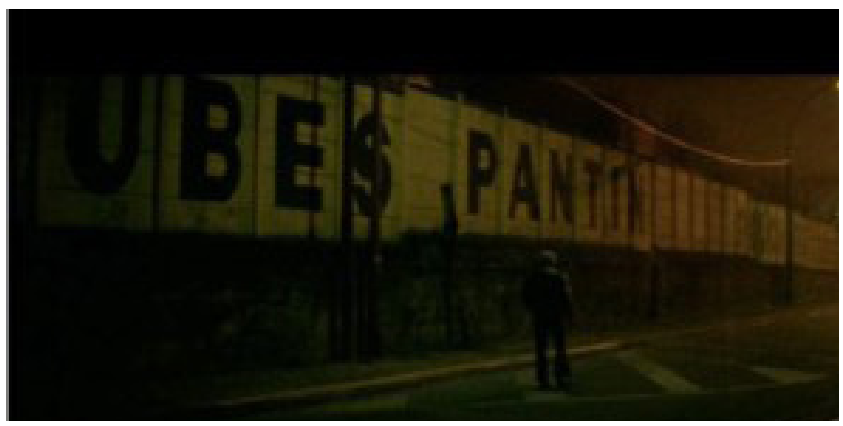

La errancia permanente y los espacios amplios, Solo contra todos, Noé

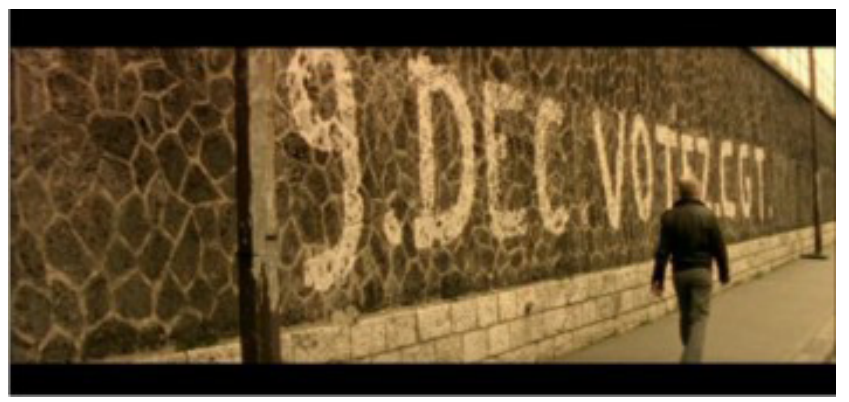

El Carnicero no presta atención a lo que lo rodea, es decir, a lo social [ “9 DIC. VOTÁ A LA CGT”], Solo contra todos, Noé

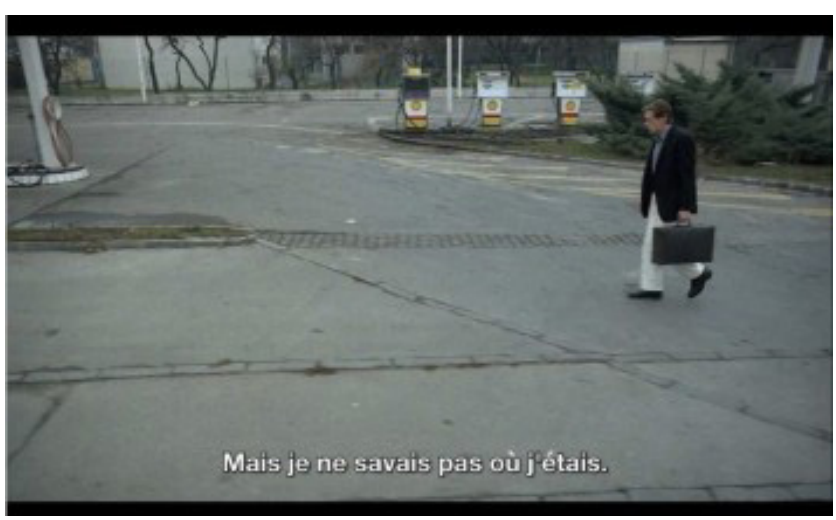

La errancia permanente del asesino, con la revelación de sus pensamientos ["Pero no sabía en dónde estaba”], Angst, Kargl

El Carnicero se autoexcluye y desarrolla el "sindrome del sobreviviente" (Furtos, 2009), es decir, no pierde nada en la realidad (por el momento, tiene un trabajo, una especie de familia, y también una "moral”), pero sí en su cabeza, aunque los hechos no hayan cambiado.

Esa soledad, esa errancia permanente, se suma a una gran cantidad de traumas infantiles.

El derrumbe simbólico subjetivo se origina en, al menos, tres elementos de la vida del Carnicero: el abandono materno, la no elaboración de la deportación de su padre, y el trauma infantil producto de la violación que sufrió a los seis años, el "robo de la inocencia en nombre de Jesús".

El derrumbe simbólico lo enfrenta, entonces, a una angustia pura de lo real.

Ese derrumbe simbólico provoca la "congelación del yo" (Furtos, 2009); dicho de otro modo, el sujeto sigue vivo, pero está anestesiado. Aquí, El Carnicero rompe con la realidad, vagabundeando, insultando, golpeando; la errancia "se convierte en una manera de amar a la distancia”, según Furtos (2009). Aquí, la errancia se convierte en una manera de odiar "en voz en off".

Sin embargo, El Carnicero no se queda en esa errancia "en off". El derrumbe simbólico que experimenta tiene una gravedad extrema y lo conduce al (los) pasaje(s) al acto.

\section{b. Del derrumbe a los pasajes al acto}

Al fenómeno que Furtos (2009) denomina "congelación del yo" puede seguirle otro fenómeno gravísimo: la "descongelación brutal del yo". En efecto, para Furtos, la descongelación del yo se opera cuando la "sangre psiquica" circula demasiado rápido; lo que resulta doloroso, como un garrote de tortura. Esto tiene dos efectos posibles: o bien el sujeto vuelve a anestesiarse, o bien se opera el pasaje al acto. El pasaje al acto puede definirse 
como la salida del lenguaje: las palabras ya no bastan para enunciar lo que se tiene para decir y "salen" en la forma pulsional del acto. Dicho de otro modo, se opera una ruptura en la relación con el Otro y en la relación con el mundo que lo rodea. El sujeto sale de su subjetividad. El pasaje al acto es, entonces, una ruptura de la cadena que une lenguaje con acción. En el pasaje al acto, la acción deja de lado la palabra en beneficio de la pulsión.

El beneficio de ese proceso (del pasaje al acto) es que el sujeto se siente todopoderoso. El pasaje al acto está siempre relacionado con la angustia. En el caso del Carnicero, se articula con su errancia, que le impide inscribirse en una historia y en una continuidad de existencia. En El Carnicero, los pasajes al acto son transgresiones de la ley: remiten a lo que denominamos "derrumbe simbólico”, es decir, la imposibilidad del sujeto de remitirse a la Ley simbólica (el incesto y el asesinato, que caracterizan los pasajes al acto del Carnicero, dan cuenta de ello).

En psicopatología, ese proceso caracteriza lo que se llama "estado límite", es decir, el estado de una persona cuya relación con la Ley se pervierte.

El Carnicero pasará al acto cada vez que la angustia de la soledad lo desborde y esos pasajes al acto traducirán su desobediencia simbólica, es decir, su incapacidad para elaborar sus faltas y privaciones.

En el fondo, El Carnicero se debate con la depresión, incluso con la melancolía. La solución del pasaje al acto en cualquier circunstancia revela la falta de seguridad interna del Carnicero o, dicho de otro modo, su extrema fragilidad narcisista.

Esos pasajes espontáneos, inesperados, que operan en los actos, representan un momento de ruptura en el que lo Simbólico está ausente y lo Real prevalece.

Sin embargo, algunas secuencias muestran que el pasaje al acto, en El Carnicero, se sitúa en el punto de contacto del fantasma y de la realidad; por ejemplo, cuando imagina que mata a su hija, se trata de un pasaje al acto en su fantasma. Noé enfrenta al espectador a ese fantasma haciéndolo pasar por real; entonces, tenemos la impresión de estar en la realidad, cuando estamos, mal que bien, en el Imaginario.

Por otra parte, la pulsión y la impulsividad asociadas al pasaje al acto son siempre del orden de la violencia.

Estas palabras remiten, sorprendentemente, al libro $\mathrm{La}$ Palabra o la Muerte de Moustapha Safouan, que es un "ensayo sobre la división del sujeto", pero también a una cita de Jacques Lacan (1966): "En los confines donde la palabra dimite, comienza el terreno de la violencia” ( $\mathrm{s} / \mathrm{d}$ ).

En efecto, podemos notar que, a lo largo de toda la película, la violencia (física o verbal) toma la delantera cuando El Carnicero ya no tiene nada más para decir, cuando su palabra se ausenta, especialmente porque sus pensamientos en voz en off no se dirigen a nadie, por lo que no tienen valor de palabra.

Asimismo, la definición de Amal Hachet (2015) resulta útil para enriquecer nuestro cuestionamiento: " $\mathrm{La}$ acción es un lugar del decir y, al mismo tiempo, un lugar de transgresión de una ley simbólica" (p. 127); aunque, en El Carnicero, el pasaje al acto da cuenta, sobre todo, de su imposibilidad para elaborar.

Podemos tomar como ejemplo la secuencia de la "separación” entre El Carnicero y La Patrona. En efecto, esta secuencia se desarrolla después de la proyección de una película pornográfica que El Carnicero va a ver, donde vuelve a afirmar, en sus pensamientos, su extrema masculinidad heterosexuada, lo que él piensa que es la virilidad, así como lo que piensa que lo define: "Mirá, si pudiera volver a empezar una existencia, debería hacer películas porno. Al menos abi está claro. La gente que hace eso entendió perfectamente el sentido de nuestra especie. O nacés con una pija, y no sos útil a menos que te comportes como una buena pija dura que llena agujeros, o nacés con un agujero, y no serás útil a menos que te dejes llenar bien. Pero, en los dos casos, estás completamente solo. Sí, yo soy una pija. Es así. Soy una miserable pija. Y para que me respeten, tendré que estar siempre bien duro".

Luego, viene la confrontación con La Patrona: ella lo acusa de haberla engañado a raíz de un malentendido de su vecina Fabienne, quien le dijo que él "estaba con una putita esa mañana”, cuando él solo había acompañado a la enfermera hasta la puerta de su casa. En ese momento se da el pasaje al acto: cuando el insulto "puto" irrumpe en la mente del Carnicero, este propina una golpiza a su mujer, en el vientre, cuando ella está embarazada de su propio hijo. De este modo, el significante "puto" hace estallar el significante al cual El Carnicero se aferraba ("una buena pija dura que llena agujeros") y que pensaba que lo definía. El encuentro entre ambos significantes es literalmente insoportable. Ya sea que se relacione con él o no, no puede soportar ninguna dimensión. Ese significante, "puto", produce una efracción en su mente, en su identidad masculina, que intenta construir (al menos, que intenta obligarse a pensar) a lo largo de toda la película, por ejemplo, dirigiendo a todo el mundo insultos como "puto", o también "culeado de tu raza". " Noé confiere más fuerza aún a la palabra "puto" [pédé] haciéndola aparecer en un intertítulo blanco sobre un fondo negro, posiblemente para subrayar su importancia, y la repercusión de ese significante. 
El pasaje al acto opera tras esa colección de insultos. El Carnicero propina un violento golpe con la rodilla al vientre de La Patrona, lo que la hace gritar. Luego, se pone a asestarle fuertes puñetazos, siempre en el vientre, como si quisiera, además de herir a su mujer, herir, o incluso matar, a su hijo nonato, aunque no lo considera como "su" bebé (como respuesta a los quejidos de la Patrona, responderá, agresivo: “ ¿Tu bebé, decis? ¿No ves que abora tu bebé no es más que un bife, un pedazo de carne reventado? ;Al menos va a tener la suerte de no verte nunca la cara!").

De este modo, El Carnicero retoma el camino de la precariedad, ya que "con 300 mangos en el bolsillo, no sabe cómo [va a] salir adelante", aunque espera obtener cierta solidaridad de parte de sus amigos, "en fin, es lo que vamos a ver".
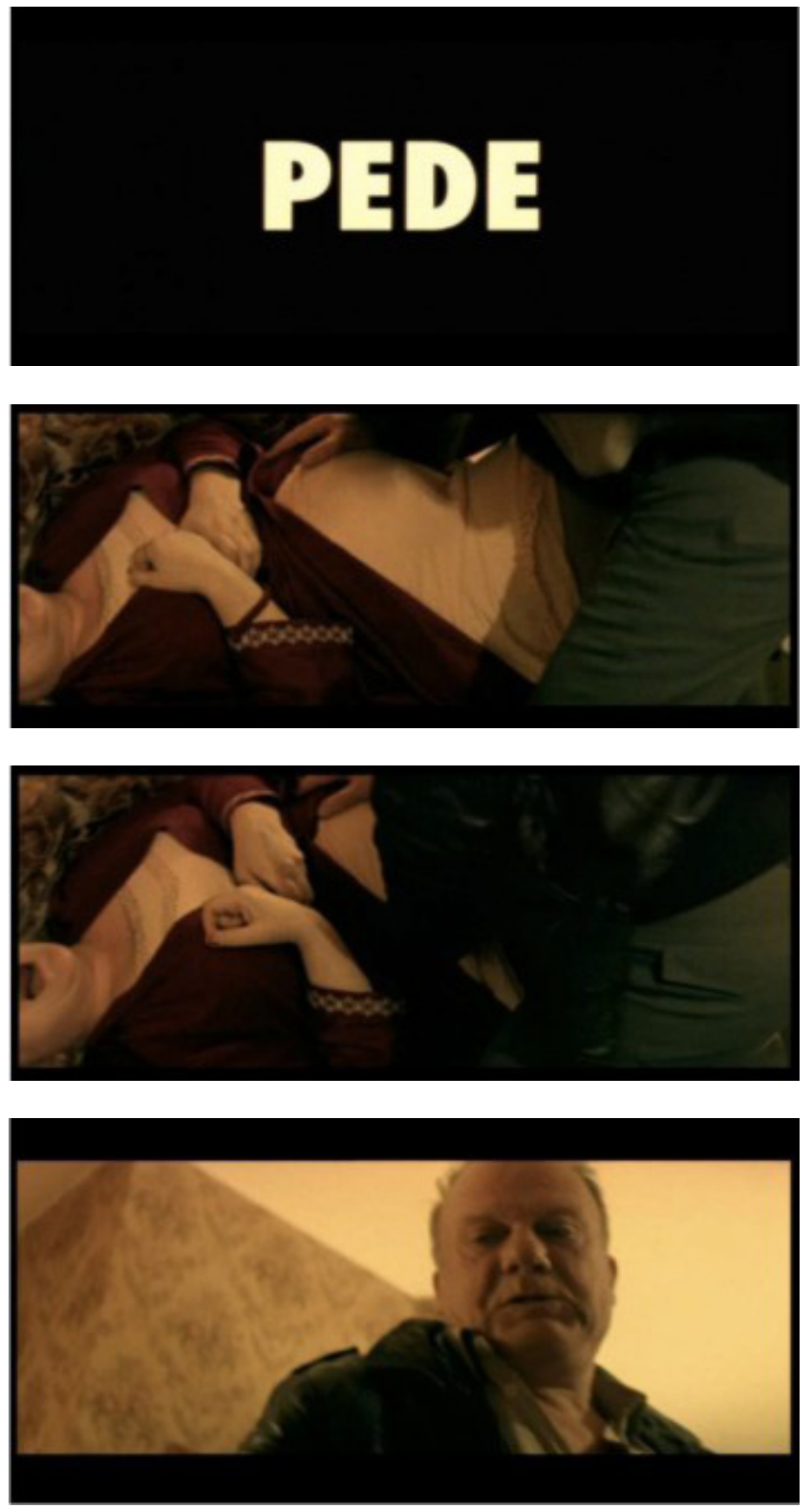

El pasaje al acto, Solo contra todos, Noé

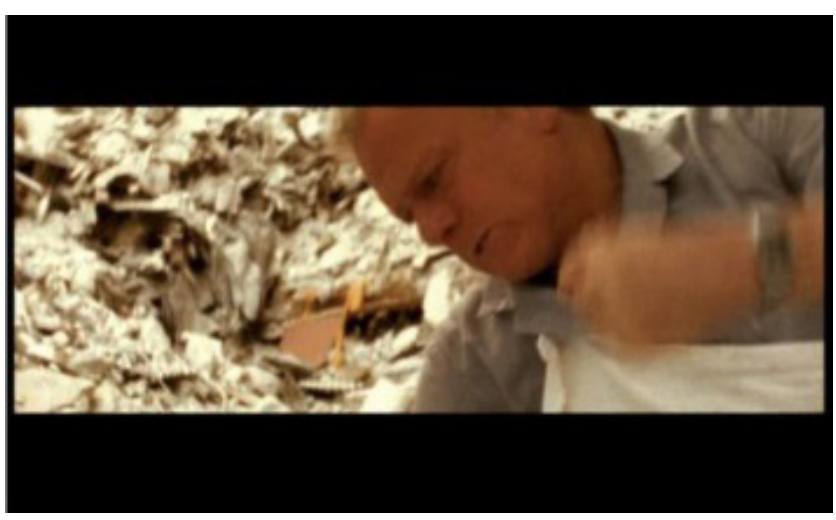

El pasaje al acto, Carne, Noé

\section{c. Fragilidad psíquica, precariedad social}

En su libro, Furtos (2009) enuncia que "la buena precariedad es la de quien grita para tener y a quien se da" (p. 21), y define tres niveles de precariedad. El primer nivel, que él llama "precariedad común" (p. 21), es el hecho de estar solo y, por lo tanto, no poder vivir. Para vivir, es necesaria la presencia de una alteridad, pero esa alteridad está justamente presente. A su pesar, El Carnicero pasa de la pobreza (el hecho de tener poco, de no ser necesitado, lo que, por definición, no impide ni la cultura ni el desarrollo) a la precariedad. Con ese cambio de "estatus social”, comienza un cambio de estado psíquico que provoca muchos cambios en la relación que El Carnicero mantiene con el mundo. En efecto, tras su partida de los suburbios de Lille, El Carnicero se encuentra en Aubervilliers, un suburbio parisino, su ciudad de origen, y decide ir a pedir dinero prestado a sus viejos "amigos".

Entonces, vemos al Carnicero deambulando entre antiguos conocidos, pidiendo algo de ayuda, solo recibiendo negativas, aunque algunas de estas no se deben únicamente a la pobreza financiera; en efecto, algunos no pueden darle dinero, pero le ofrecen recibirlo algunas noches, o bien darle un "pedazo de pan". Sucede lo mismo cuando va a la agencia de trabajos temporales, o incluso a buscar a antiguos contactos profesionales: no hay ningún puesto disponible. Pedir ayuda, saber cómo pedir ayuda, tener esperanza y saber recuperarse de los fracasos y de las desilusiones tiene una importancia capital, aunque El Carnicero no logra hacer frente a esos rechazos y gestos de desprecio. Nuevamente, aparece un discurso homofóbico y marginal sobre la tragedia de la que Francia es víctima (¿o culpable?), lo que suscita un discurso reaccionario, y vuelve casi irónicas las inscripciones en las paredes frente a las cuales El Carnice- 
ro desfila continuamente: "9 DIC. VOTÁ A LA CGT". Esto demuestra aún más la fragilidad psíquica de la que El Carnicero es víctima; la escena previa a sus pedidos de trabajo y dinero se desarrolla en un café cualquiera, donde El Carnicero se enfrenta a una escena de racismo virulenta: un cliente "árabe" pide un café, el mozo le responde que "si querés té de menta, ${ }^{7}$ tenés que cruzar la calle, es enfrente", el tono sube y el discurso nacionalista de "esta es nuestra casa" domina la discusión que acabará con un "agarrá tus babuchas, da la vuelta y andate”, dicho con gran violencia. Esta escena, a la que El Carnicero asiste, lo afecta, en el fondo parece que no piensa de un modo tan radical como sus pensamientos nos hacen imaginar, aunque no hace nada para defender al cliente discriminado.

El Carnicero es un personaje totalmente ambiguo, ya que es narcisísticamente inestable. Esa escena de racismo le desagrada, pero su discurso homofóbico y racista no se calma. Cuando su antiguo proveedor le rechaza su pedido de empleo por tener antecedentes penales (que justifica diciendo que estuvo "algunos días demorado" pero "por un error judicial. Creía que habian tocado a [su] hija"), una vez terminada la entrevista, se indigna (El Carnicero no para de indignarse cuando no hay nadie presente para verlo u oírlo). Sus pensamientos, que se nos revelan, demuestran una frustración preponderante: " $i Q$ ue me trate asi un putito? ¡Díganme que estoy soñando! (...) iQué linda es la France Chevaline! ${ }^{8}$ Qué hipócrita. Me da vergüen$z a$ que ese tipo sea francés. Si a Francia la dirigen tipos como él, estamos realmente en el reino de los hipócritas. (...) Debería haberlo golpeado abi mismo, a ese miserable. Un zapatazo en la cara para que mostrarle mis antecedentes". Su discurso se torna cada vez más violento y termina con una moraleja que podríamos sintetizar como "todos son una mierda, menos yo": "Pero hoy, todos son demasiado maricas para hacer la revolución. Solo puede haber venganzas personales. jEso sí! ;Como la mía! Pero va a ser útil para el conjunto. Si Robespierre es un gran héroe nacional, yo también voy a serlo, pero en una escala más chica. Matando a ese gordo cerdo burgués homosexual que me niega el trabajo porque estuve en la cárcel. ¿En serio? ¿Quiere que me convierta en un vagabundo asi se la chupo por veinte centavos? ¿Eh? ¿Ese es su plan? Bueno, yo le voy a mostrar qué es la violencia, la violencia de verdad. Los cincuenta años de bumillación que me tuve que tragar, él, el marica, los va a vivir en seis minutos. Seis minutos de pura violencia física". Entonces, todas sus relaciones con los otros son inciertas y problemáticas, lo que contribuye a encerrarlo más todavía en la soledad de su interioridad. Esta reflexión nos lleva a otra pregunta: ¿vivir es más difícil que sobrevivir? (Benhaim, 2012).

Cuando El Carnicero se enfrenta a todos esos rechazos, el vuelco del fantasma a lo Real se produce de un modo violento. El Carnicero, por quien era posible sentir empatía como espectador, se convierte en una persona colmada, exclusivamente, de desesperación (ya no tiene nada y nadie responde a sus llamados de auxilio) que se transforma, muy velozmente, en un odio profundo hacia los otros y hacia sí mismo. Con respecto a los sin techo que viven en una gran precariedad, Benhaïm (2012) expresa que "en lo real, y ya no en el fantasma, el sujeto es un desecho o, más precisamente, se identifica, en lo real, con el desecho del Otro"; si aplicamos esos escritos al caso del Carnicero, podemos observar que él, que en su Imaginario se imagina como un desecho, también lo es en la mirada que el otro o los otros le dirigen. Eso lo conecta con lo real. Esa imagen que los otros tienen de él, como de alguien en situación de gran precariedad, le hace tomar conciencia de esa precariedad en lo real, ya que está realmente excluido de la sociedad, realmente es un sin techo, un desempleado y está solo.

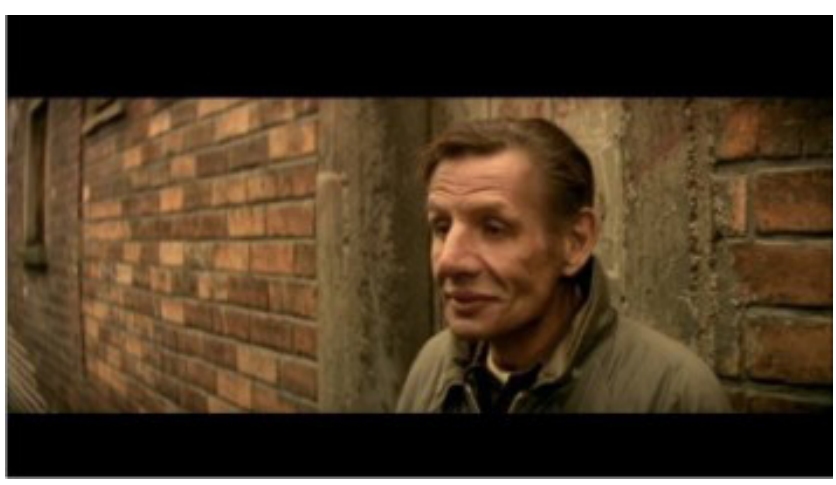

Uno de los “amigos" del Carnicero, también en situación de precariedad, Solo contra todos, Noé

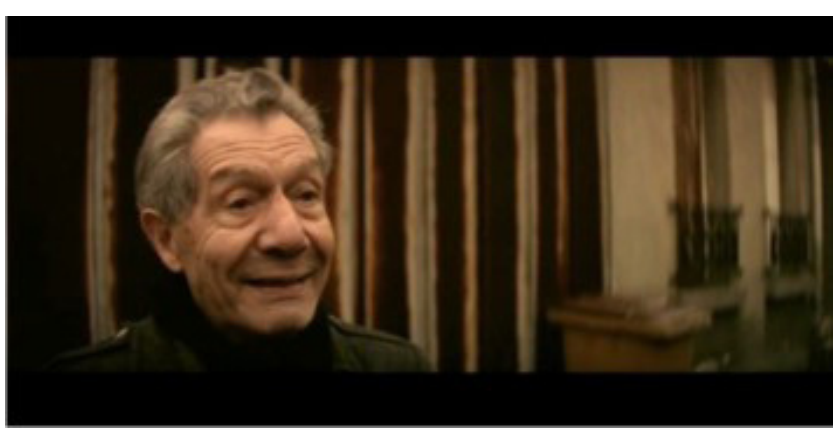

Uno de los amigos del Carnicero, con una sonrisa en los labios, a pesar de su situación precaria, Solo contra todos, Noé 


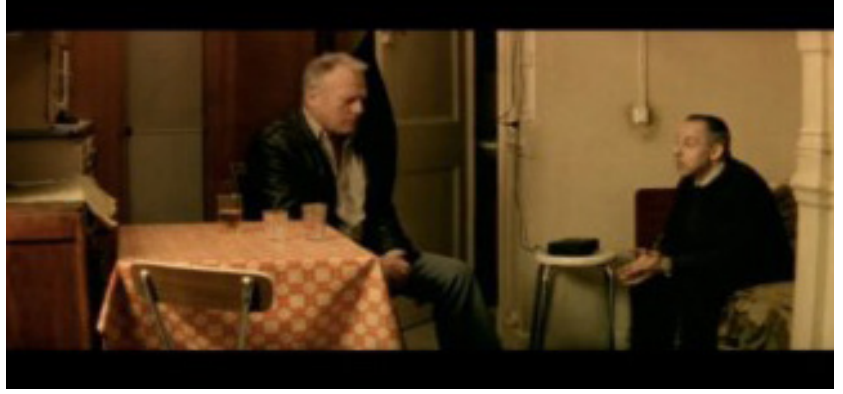

El Carnicero pide, pero nunca mira a los ojos, Solo contra todos, Noé

\section{2. "Contra": El Carnicero como figura del "criminal-víctima"}

"Declaró que yo no tenía nada que hacer con una sociedad cuyas reglas más esenciales desconocía y que no podía invocar a ese corazón humano cuyas reacciones elementales ignoraba”. Albert Camus (2005).

\section{a. Del trauma inicial a la lógica: el otro o yo}

El Carnicero justifica toda negativa de recurrir a sus reservas, agotadas, atribuyendo todo a las adversidades traumáticas del pasado: pérdida de su mujer, violación, pérdida de empleo, crimen (intento de homicidio). Portador de un discurso sobre esta sociedad, se embarca en una lucha personal para preservar lo que él considera que es hacer justicia por mano propia.

Siempre con el mismo tono violento, la voz en off empieza a perder todo sentido y lógica, reflejando la desesperación del sujeto. En cierto modo, el espectador se encuentra traumatizado al mismo tiempo que El Carnicero, en estado de inseguridad.

En el sujeto humano, la construcción de la alteridad pasa por el otro: como señalamos antes, El Carnicero sustituye a su Otro caritativo, el Nebenmensch, por su pistola. La falla se remonta al inicio de la vida del Carnicero. Su trauma inicial, es decir, el abandono de su madre, conduce al Carnicero a construirse únicamente con partes del mundo caóticas. Su alteridad, es decir, su relación con el Otro, falla desde el principio de su existencia. Eso genera, entonces, una forma de amenaza permanente de todo lo que lo rodea. No está en una lógica del "vivir juntos", es decir, "yo y el otro", sino en una lógica de exclusión, "el otro o yo".

Nadie cae en gracia a los ojos del Carnicero, excepto su hija, Cynthia. Sin embargo, esta no habla, es muda y su relación es ilegítima, incluso incestuosa.
De este modo, a lo largo de su "epopeya", de su deambulación, de su errancia, cruza "otros" que, según El Carnicero, contienen una dimensión persecutoria, excepto sus viejos "amigos", que también han caído en esos mismos procesos precarios de exclusión psíquicos y sociales. Son las únicas personas con quienes no es violento, a pesar de los rechazos que recibe continuamente. Sin embargo, no los volverá a ver, es decir, no los considera como "otros" posibles.

Ninguno de esos otros que cruza es ni podrá ser caritativo. Todos están predestinados a la exclusión puesto que, tanto en ellos como en El Carnicero, no hay, aparentemente, huellas de una consciencia de clase. El fracaso de la "izquierda" -la de los años 80- no ofrece un contexto favorable para el surgimiento de dicha consciencia. Nadie frecuenta los sindicatos o las asociaciones, lo cual produce un aislamiento sin precedentes. El Carnicero está aislado, y se aísla solo. Vive su destino social como si fuera un destino individual, es decir, un destino reservado exclusivamente a él, cuando en realidad se trata del cotidiano de casi la totalidad de sus conocidos. ¿Esa es la razón por la cual nunca podrá prestar auxilio, por ejemplo a la vieja que agoniza en el asilo, o bien a la enfermera?

Los dos ejemplos explicitados aquí arriba muestran que El Carnicero se encuentra atrapado en un proceso de alienación con respecto a las relaciones sociales, es decir, es ajeno a sí mismo, lo que provoca una especie de falla en la construcción de su alteridad.

Cuando no es violento, El Carnicero es pasivo, se hunde en sus pensamientos más oscuros, que se nos revelan. No tiene absolutamente ningún impulso hacia el otro, dado que su construcción defectuosa de la alteridad provoca una relación particular, incluso problemática, con la realidad.

Eso lo suele volver interpretativo, incluso un poco paranoico.

Para El Carnicero, esos "otros” están en el centro de sus fantasías de asesinato, como sucede con el patrón del matadero, después de que se niega a contratarlo por su "fichita", o con el joven de la barra, que parece menospreciarlo por no tener suficiente dinero para pagar lo que ha consumido. Esas fantasías de asesinato se deben, la mayoría de las veces, a una humillación que sufre El Carnicero ("Los cincuenta años de bumillación que me tuve que tragar") y responden a una "venganza de clase”: " $\dot{z}$ Ves? Vos tenés una casa, un auto, ropa y plata bien guardadita en el banco. $Y$ a mí, de mis treinta y cinco años de trabajo, no me queda nada. Lo que queda de mi vida no está en tu fichita. Es este fierro. Ah, supongo que no estás acostumbrado a los fierros. Yo, en cambio, no estoy acostumbrado a la plata. 
Sin embargo, yo también habría querido tener una vida normal como la tuya. Después de treinta y cinco años de trabajo y honestidad, veo que mi antigno proveedor me trata como si fuera el más despreciable de los vagabundos. (...) Soy una mierda, pero una mierda con un fierro. (...) El desempleado te la da por el culo. Porque de todas las razas del mundo, hay una que babría que eliminar. ¿Sabés cuál? La tuya. La de los hipócritas y los traidores”; "BBastardos de mierda! Sí, yo también voy a buscar mi pistola. No me conocen todavía. No saben quién soy. Cuando la violencia te llama, nunca hay que dar media vuelta. Es un asunto de hombres. Voy a arreglar esto rápido. Y no va a ser suave. Voy a enseñarles la justicia de mi país. Cuando les apunte con el arma, van a agachar la cabeza, esas basuras. No hay justicia sin venganza. $Y$ como no soy traidor, no voy a llamar a la cana. "Soy yo en que va a aplicar esta justicia de mierda! 'Pena de muerte para esas basuras!”.

Como acabamos de ver, solo puede odiar al otro; podemos preguntarnos qué es lo que motiva ese sentimiento intenso.

\section{b. El odio al otro como intento de reparar las heridas} propias

En El Carnicero, la destrucción responde a su odio por el mundo. Este hombre perdido erra, no puede orientarse en el mundo. El odio sobrecarga al sujeto.

¿Cómo concebimos que El Carnicero se aferre a ese odio? Podemos emitir la hipótesis de que ese odio tendría un sentido para él y que sería sinónimo de solución, para (sobre)vivir. Ese odio, que se inscribe, como desarrollamos antes, en una lógica de "el otro o yo", se expresa a costa del otro, tal vez para salvar algo de la subjetividad del Carnicero. Es frágil: una mirada, una palabra, un gesto, un pensamiento lo derrumba, y hace que se derrumbe su mundo. Esa fragilidad se relaciona con una inseguridad que es el resultado de heridas precoces (abandono, violación) y más tardías (internamiento de su hija, intento de asesinato, cárcel, desempleo).

Todas esas heridas confrontan al Carnicero con pérdidas sobreacumuladas, que impiden cualquier inscripción simbólica o social: amar, dejarse amar, trabajar, etc. Lo hacen aún más frágil y, en la medida en que no tiene los medios psíquicos para elaborar sus pérdidas, El Carnicero responde en el campo de la pulsión, de la violencia y, en el caso señalado anteriormente, la venganza de odio.

Sin embargo, durante sus fantasías de pasaje al acto, y especialmente de asesinato, del final de la película, Noé nos hace creer que El Carnicero asesina a su hija Cynthia, heroína en su imaginación, de un modo extremadamente violento, antes de suicidarse, con un disparo en la cabeza, en la habitación donde Cynthia fue concebida.

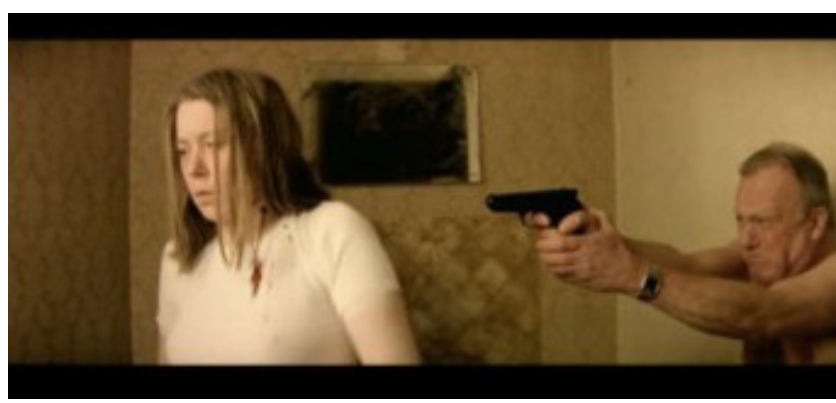

Asesinato fantaseado de Cynthia, Solo contra todos, Noé
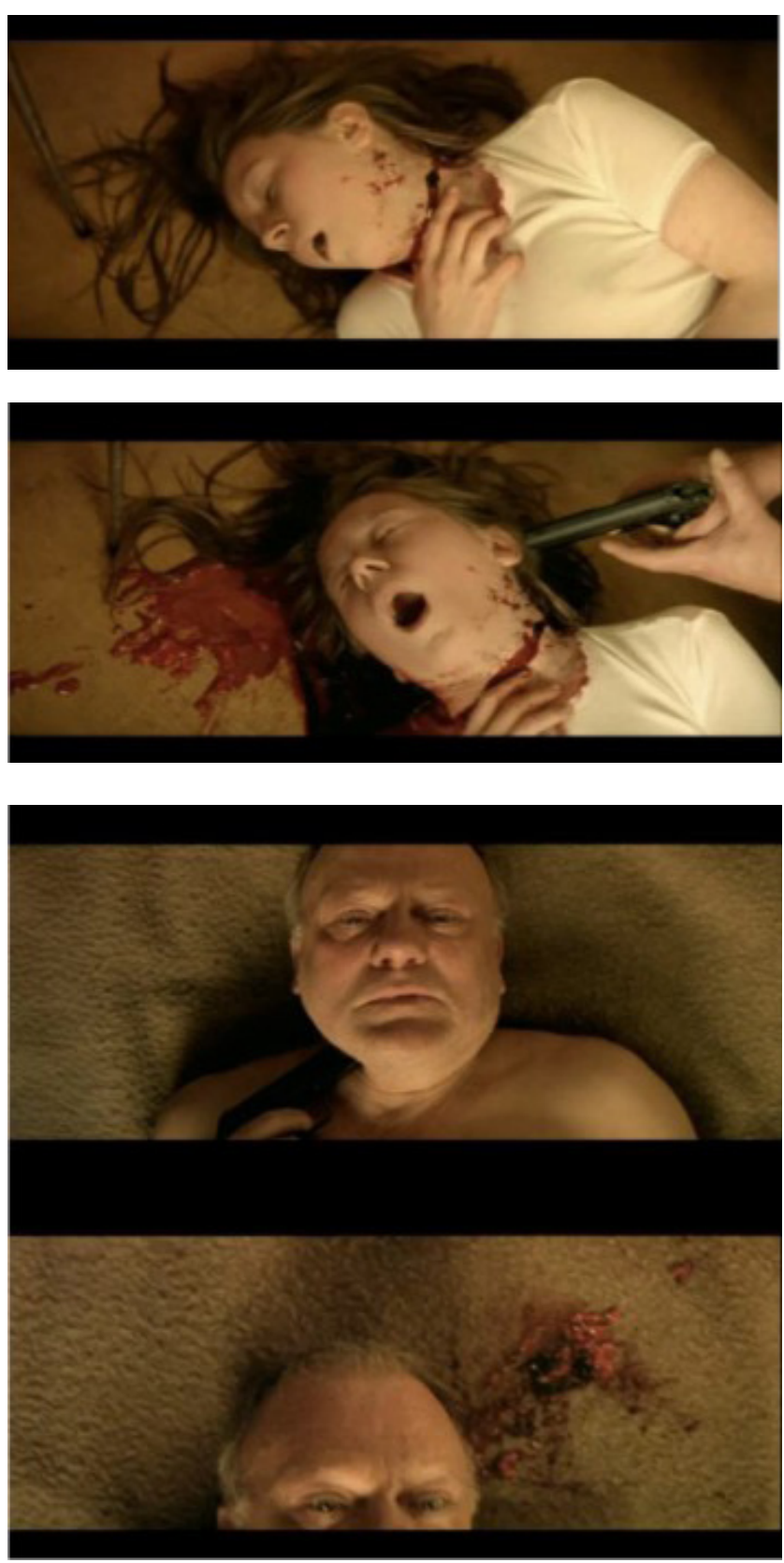

Suicidio fantaseado del Carnicero, Solo contra todos, Noé 
En realidad, El Carnicero pasa por esa fantasía de asesinato de su hija para "liberarla": "Sabés, nos vamos a ir de viaje, un viaje muy, muy largo... Solos vos y yo. Estás de acuerdo, ¿no?"; "Listo. Lo que debiamos vivir, lo hemos vivido. Y no fue tan lindo como pensaba. Ahora hay que ir hasta el final de esta angustia. Ya no tengo nada que perder. Sí, es así. Hago esto por tu bien. Es mi deber evitarte años de sufrimiento. Vas a esperarme del otro lado. Yo ya llego, justo después de vos. Pero va a ser muy rápido". Le dispara en la garganta, por atrás, y la joven agoniza a los pies de su padre.

Extrañamente, esa escena recuerda la primera escena de Carne, en la que se faena un caballo, así como Le sang des bêtes [La sangre de las bestias] de Franju (1949).

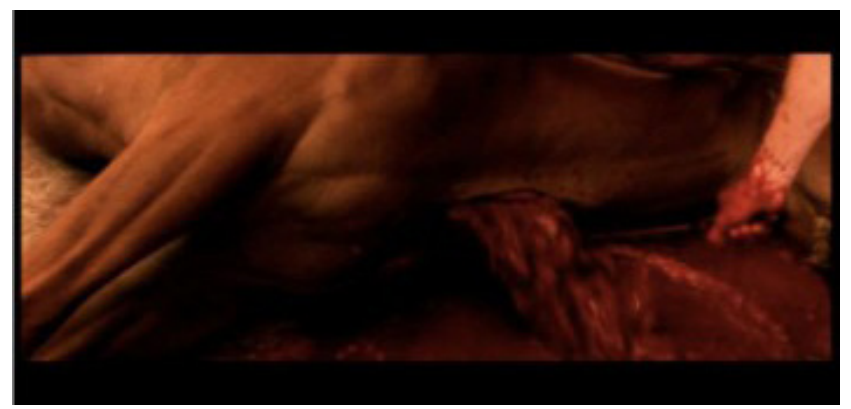

Primera escena de Carne, Noé

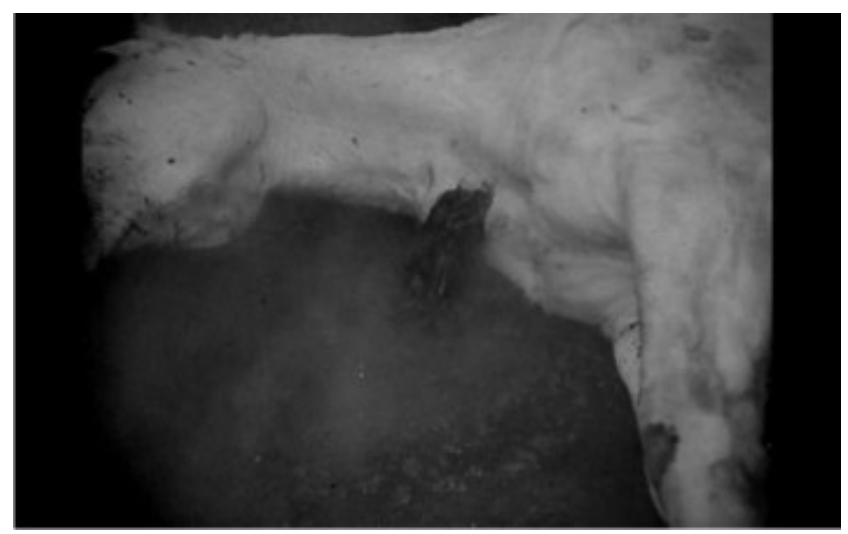

Le sang des bêtes [La sangre de las bestias], Franju

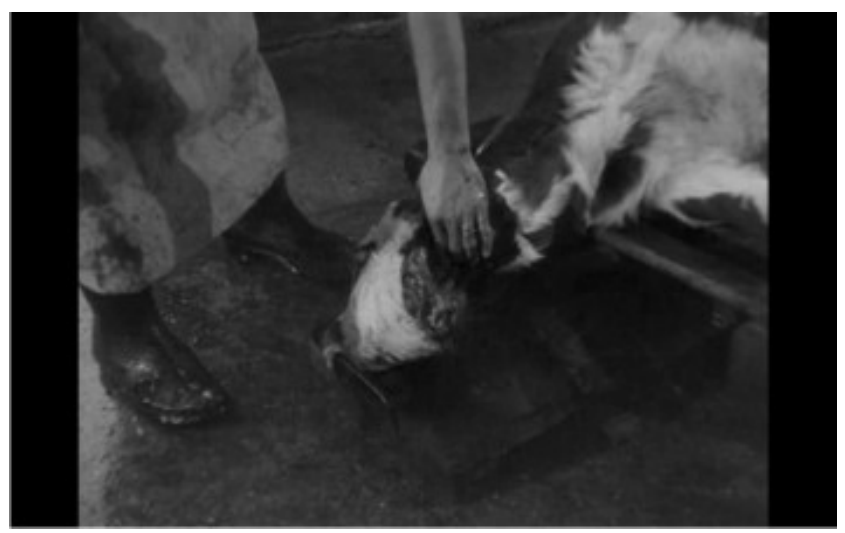

[Le sang des bêtes] [La sangre de las bestias], Franju

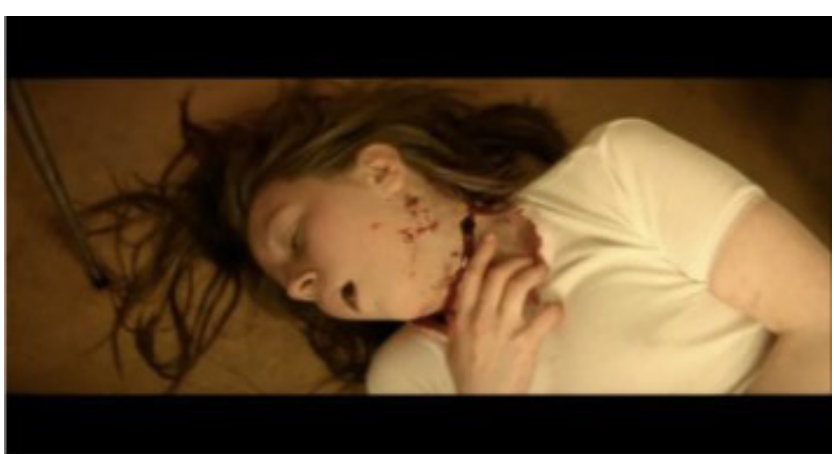

Asesinato de Cynthia, Solo contra todos, Noé

El hecho de que El Carnicero le dispare en la garganta no es menor. En efecto, durante toda la película (podemos decir, incluso, durante toda su vida), Cynthia, encerrada en su silencio, está ausente hasta en su asesinato. Le resulta imposible debatirse o pedir auxilio, es espectadora de su propio asesinato. Esa función de espectador se transmite al Carnicero después de que este mata a su hija. En efecto, tras ese acto, sus pensamientos se alborotan y empieza a acusar a un "ellos" desconocido, el "todos", dando mil vueltas; se opera una especie de despersonalización: "Han matado a mi hija. I Tiene que dejar de pensar, esta cabeza. (...) Pero alguien tocó a mi hija. I Esperá, no tenía derecho. I ¿Pero de qué hablo? I Al cabrón que bizo eso lo voy a hacer mierda. / Debo hacer que el bien gane. / Sí, voy a hacerlo mierda. / Es mi deber. / Es el obrero. / Es como mi padre, era comunista. / No es el obrero, es El Carnicero. / Él quería el bien para todos. I La mató, y se lo bicieron pagar. / No tenían derecho. / Los alemanes. I A ese cabrón tengo que matarlo. / Lo mataron porque era bumanista. (...) En cuanto a mi madre. I Él la mató. / No. / Yo sigo siendo el mismo. I ¿Ella? / Huérfano, Carnicero, desempleado. I Era el mal, todo a la vez. I Dispará si sos hombre. I Parece que era una puta repugnante que denunciaba a los judios y a los rojos con los alemanes. ¿Sos marica o qué? I En general, gana el mal. (...) iTal vez la vieja puta que me parió también me espera! / Y la otra puta que parió a Cynthia también! I Somos inocentes. / Calma. / Y el bien tiene que ganar".

Luego, sigue un recuento aterrador, trenzado con imágenes abruptas de relaciones sexuales, del cuerpo sin vida de Cynthia y del rostro del Carnicero, que tiene el arma pegada al cuello, con el dedo en el gatillo. Todo se acelera, el discurso del Carnicero se corta por el recuento y por una respiración anormal que se vuelve cada vez más fuerte a lo largo de la secuencia: "CINCO. / Esta vez, voy a ser presidente. / CUATRO. / Voy a serlo para 
vos. / TRES. / Voy a gobernar Francia. / DOS. / Y los voy a joder a todos, los que sean. / UNO. / No se van a escapar. Listo, el botón rojo. Pronto, el vacío. / Esperando I el vacío. / Solo voy a dejarles pedazos de mis sesos. Por fin, ya estoy. Se terminó. ;BUM!".

Toda la imagen se pone roja y luego un fundido encadenado nos vuelve a poner en la realidad, abriendo un primerísimo primer plano sobre el ojo del Carnicero, que mira a su hija.

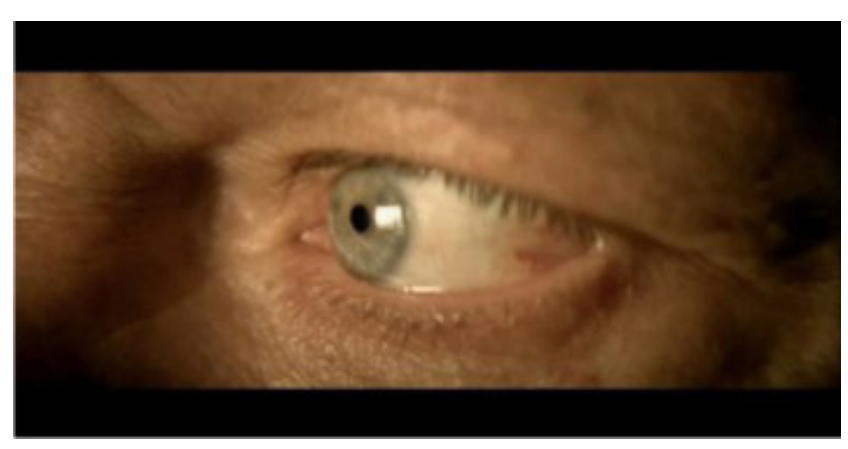

Vuelta a la realidad a través de la mirada del Carnicero, Solo contra todos, Noé

Incluso cuando el proyecto es constructivo, solo puede tomar prestada la voz de la destrucción. No obstante eso, aunque la "solución" de odio es costosa, El Carnicero está vivo y no pierde por completo la esperanza de curar su existencia.

\section{c. Los pasajes al acto como punto muerto}

"Para ser habitable, el mundo debe ponerse en escena con palabras" (Legrendre, 1995).

Un punto muerto es una voz sin salida. El pasaje al acto es una salida del lenguaje. Ahora bien, solo podemos vivir los unos con los otros si nos hablamos. El Carnicero está en un punto muerto, ya que se aferra a transgresiones en las que se inscriben las acciones que lleva a cabo. Piensa que todos sus pasajes al acto pueden cambiar algo, cuando en realidad estos le cierran el horizonte. Está en un punto muerto consecuencia de todo lo que comenzó mal desde el principio de su vida. En El Carnicero hay una particularidad: más que los actos, son las palabras/pensamientos que suelta los que resuenan como pasajes al acto.

Sin embargo, allí es donde se aloja la "humanidad" del Carnicero. La mayoría de los pasajes al acto que "comete" son pasajes a la "acción fallida": durante su altercado con el joven de la barra y el dueño del bar, promete volver para vengarse de la humillación que ha sufrido, pero vuelve al lugar cuando el bar está cerrado; todos los asesinatos se cometen en su imaginación.

Sumado a la ambigüedad de su visión con respecto a la escena racista a la que asiste, esos puntos furtivos de humanidad ratifican nuestra hipótesis: ¿Gaspar Noé es, sin darse cuenta, un cineasta de lo social contemporáneo?

La diseminación de esos fragmentos de humanidad muestra que el tema social lo excede. Lo social excede a Noé cuando se sirve de esos rastros para humanizar al Carnicero, ya que "la esencia del hombre no es una abstracción inherente al individuo aislado. En su realidad, es el conjunto de las relaciones sociales" (Marx y Engels, 2014, s/d): para El Carnicero, funciona sobre todo en la exclusión y en sus relaciones de exclusión. Las relaciones sociales en las que se encuentra, que son relaciones de exclusión, forman su esencia. Está inscrito en relaciones sociales de alienación. Allí se encuentra la ambivalencia del Carnicero, ya que, en las relaciones sociales, puede haber relaciones que humanicen.

La especificidad del pasaje al acto está en la dimensión de violencia que contiene; violencia que surge brutalmente, de modo inesperado, en todo momento. En ese sentido, podemos hablar de efracción. El pasaje al acto contribuye a aumentar la profunda soledad del Carnicero: al ejercer efracción sobre el otro, este último se aleja.

Así, el pasaje al acto responde a la lógica de "el otro o yo", y constituye un punto muerto relacional, es decir, humano.

Cuantas más veces El Carnicero pasa al acto, más se repliega sobre sí mismo, más lo amenaza el mundo, más se aísla, más se despoja de su subjetividad. Esa desposesión alimenta, repetidamente, los pasajes al acto. Podemos ver la dimensión de punto muerto a partir de ese círculo vicioso. El Carnicero se convierte, entonces, en su propia víctima.

\section{3. "Todos": Un mundo vacío que el prójimo ha abandonado}
"Y la madre, cerrando el libro del deber, se iba satisfecha y orgullosa, sin ver en los ojos azules y en la frente combada, el alma de su hijo al asco abandonada.". Arthur Rimbaud. ${ }^{9}$

El Carnicero, solo, está contra "todos", es decir, no "con los otros", sino a pesar de "todos" los otros. Aquí, el "todos" atañe a una totalidad sin distinción, y parece 
tener por función intensificar el "solo". En principio, entonces, el "todos" no da ninguna oportunidad ni ofrece ninguna apertura: "todos" es cualquiera que se acerque para romper la soledad, "todos" no es un colectivo sino un bloque, una entidad más totalitaria que unitaria, sinónimo de la no afiliación del Carnicero a lo que fuere -sindicatos, asociaciones, etc.-. De este modo, el uso de la palabra "todos" es la expresión misma de la experiencia de soledad del Carnicero, ligada a lo trágico y al sufrimiento.

a. Ser, no con los otros, sino a pesar de "todos" los otros

¿Es ese "todos" lo que El Carnicero percibe en el espejo? En el fondo, ¿contra quién se dispone a disparar? La fase del espejo (Lacan, 1966) supone un instante fundador en el que, a través de su reflejo en el espejo, el sujeto toma consciencia de sí mismo y de la unidad de su cuerpo. Aquí, ese cuerpo no deja de volar en pedacitos -el suyo, el de los otros, incluido el de su hija, en su fantasía-, ni de hacer que se desarme el cuerpo del otro: el asesinato del bebé en el vientre de su madre.

Allí donde la película El espejo de Tarkovski (1975) ${ }^{10}$ recuerda justamente que el hombre no está solo en el mundo frente a todo lo doloroso que contiene la existencia, que es humano compartir esos dolores con los demás en una especie de compromiso (que Lévinas llama "la responsabilidad por el otro") la película de Noé parece ofrecer muy poca esperanza: la escena del espejo, la voz en off, interna, del Carnicero frente al rostro, no del otro sino de sí mismo, da cuenta de ello.
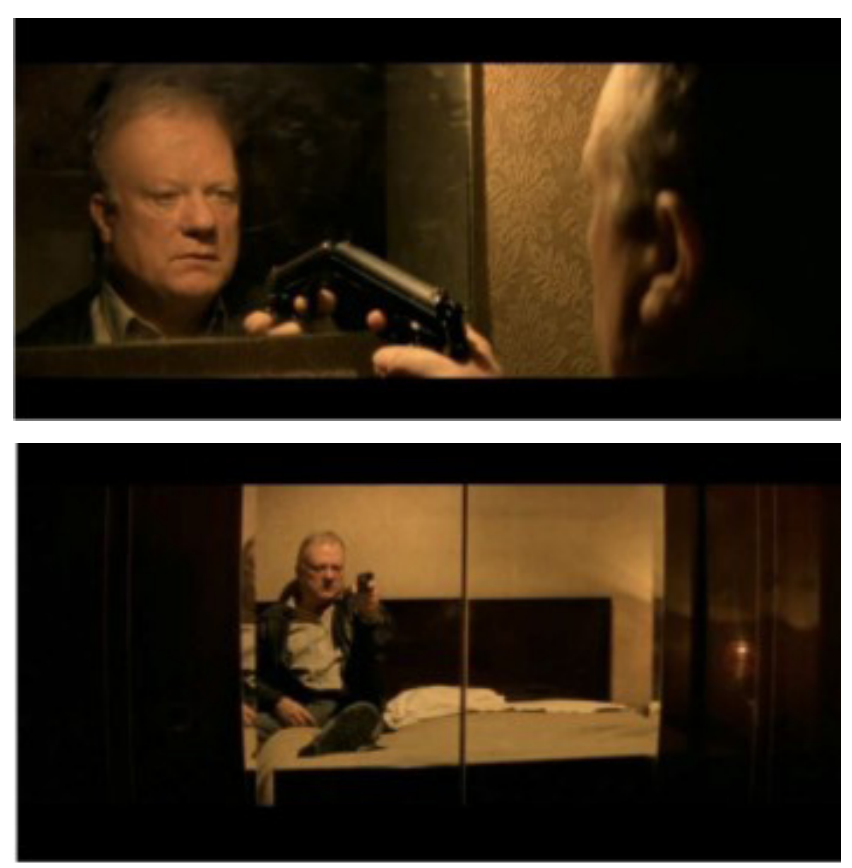
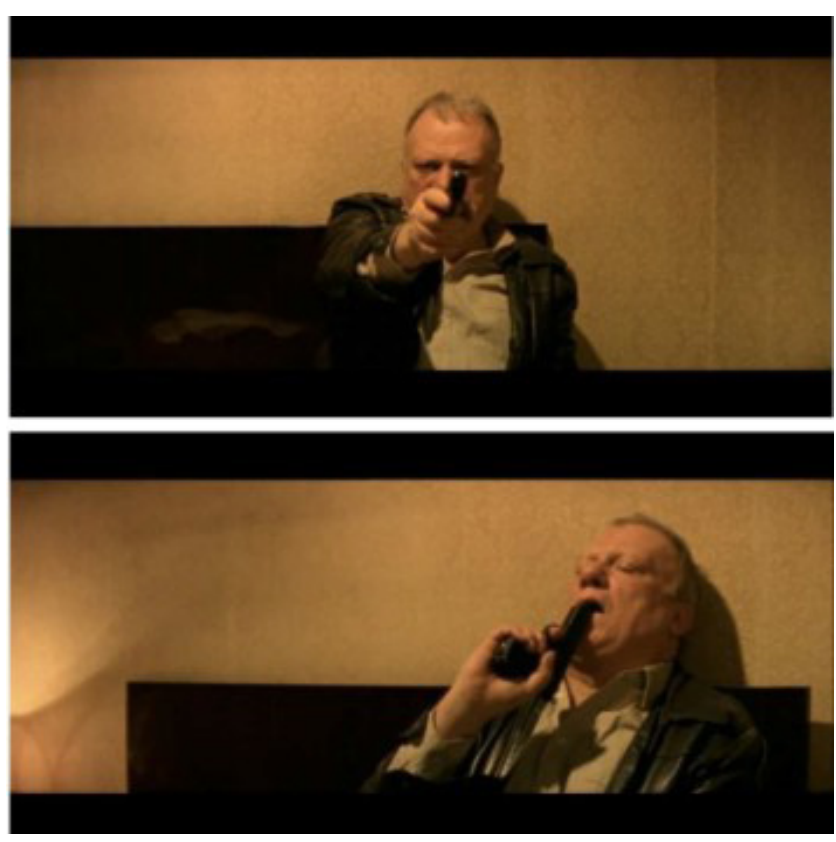

Escena del espejo, Solo contra todos, Noé

Sin embargo, El Carnicero está "solo contra todos", pero también está "muy cerca de" 11 su hija.

La soledad social, la incapacidad para afiliarse, entablar una relación de amistad, incluso amorosa, hace del protagonista un hombre solo, imposibilitado para inscribirse en lo social; está desafiliado: por la ausencia de un trabajo de duelo con respecto a sus padres, especialmente su padre, no se siente sostenido por una filiación paterna que, además de traumática, ni siquiera tiene nombre, y está desafiliado socialmente, ya que está imposibilitado para relacionarse con cualquiera. Dialoga consigo mismo, se cuenta su propia historia en voz alta, incapaz de compartir, de asociarse con nadie, un amigo, un grupo, una asociación, un sindicato. Solo en el mundo más que contra el mundo, ese mundo hecho de miserias, injusticias, de una moral inexplicable, insoportable para él, debido a su sufrimiento individual, se queja pero no hace nada para cambiar las cosas, está "desocializado" en lo social. Aunque el protagonista, en cierto modo, elabora y simboliza en voz alta, en una especie de monólogo interior, no llega a entablar un lazo social, no quiere. Nada lo sostiene en lo social, solo su rencor, incluso su odio.

\section{b. "Todos", entidad totalitaria, como expresión trágica de la soledad del Carnicero}

El término "todos" puede significar la suma de muchos otros con los que nos relacionamos, pero aquí, ese "todos" es anónimo: es un bloque, una masa. No se destaca ningún "otro" singular. Por eso no deja entrar 
ninguna luz, no ofrece ninguna apertura y alimenta la certeza del Carnicero, que mete a "todos" en la misma bolsa: perseguidores, en algunos casos, que deben ser abatidos. Nadie puede enfrentar a un "todos" percibido de ese modo. El menor encuentro remite a una invasión, una intrusión, una agresión, y desborda al Carnicero con angustia y odio. El "todos" es soportable en un vivir juntos, si no se trata de una entidad que es, necesariamente, enemiga, una total amenaza. No es posible vencer "solo" a una entidad cerrada y totalitaria.

El Carnicero es, para sí mismo, su propio vacío, en la medida en que ha roto todo lazo con la comunidad de los hombres.

El Carnicero se siente excluido de los lugares significantes de la integración, se queda inmóvil en una posición de víctima, sin aceptar aquello que se le propone, lo que limita los medios posibles para reconstruir su historia.

El Carnicero cuestiona el sentido de la vida y del mundo. Lo trágico de su soledad está en el centro de su desamparo. La tragedia se perfila como un estar "solo" confrontado a un "todos" sin forma y se enuncia en su pasión de odio.

Solo contra todos es una tragedia, de esas que exploran las pasiones bumanas, demasiado bumanas. El Carnicero no es un personaje ilustre, es un anónimo en lucha contra conflictos internos intensos y un destino desdichado, ineludible: su historia atañe a lo que podríamos denominar "una tragedia proletaria".

No hay escapatoria posible y los decorados de la película refuerzan esa idea: perspectivas aplastadas, calles vacías, paredes grafiteadas, altos paredones de fábricas se apropian de la imagen a lo largo del desplazamiento del Carnicero.

Cuando André Green (2007) dice que

la transformación que se da en la vida psíquica, en el momento del duelo repentino de la madre que desinviste brutalmente a su hijo, es vivida por este como una catástrofe (...), constituye una desilusión anticipada y (...) provoca, además de la pérdida de amor, la pérdida de sentido, ya que el bebé no dispone de ninguna explicación para dar cuenta de lo que se ha producido. (s/d)

Resumido como su concepto de la "madre muerta”, remite directamente a la situación del Carnicero, así como a la de su hija. En efecto, ambos protagonistas no conocieron a su madre, ya que fueron abandonados tras su nacimiento.

Tragedia en la tragedia, la ausencia del padre como fundador del acceso a lo simbólico deja a ese niño en la des-errancia. El abandono de la madre lo llevará a repetir situaciones mortíferas respecto de las mujeres, con quienes mantiene relaciones deshumanizadas y deshumanizantes: violencia, desprecio, odio por las mujeres, ¿puede entenderse como una venganza con respecto a su madre, que lo abandonó? A su propia hija la abandona su madre: la tragedia se repite. Pero la repetición no se termina allí: lo prueba la relación incestuosa que tiene con su hija, como la que él tuvo con el sacerdote. Lo social es el trauma que se repite, y le "roba su inocencia" por segunda vez. Aquí, lo social aparece como un mundo cerrado, un universo replegado en sí mismo, donde no hay ninguna apertura política, ninguna lucha organizada, ninguna esperanza más allá de una lúgubre repetición. En el interior de ese "mundo cerrado", el sujeto repite y reivindica su soledad, incluso su misoginia y homofobia, intentando justificar sus actos según su propia moral y su propia justicia.

\section{Conclusión: ¿El Otro?}

Finalmente, la alteridad, es decir, la relación social, surge en su vida donde él no la esperaba. Esa alteridad imprevista es lo que vuelve a llevar al Carnicero a lo simbólico, del griego symbolon: objeto dividido en dos que constituía un signo de reconocimiento cuando los portadores podían reunir ambos trozos. El Carnicero descubre lo simbólico al descubrir "el amor incestuoso". Se enamora de su hija, carne de su carne. Es una película sobre la carne; como carnicero, el trabajo de la carne es su oficio, pero esto va mucho más lejos: tiene una relación carnal con el mundo, El Carnicero se encuentra del lado de lo arcaico.

Cuando vuelve a lo simbólico, descubre que el Otro existe, pero se asocia con la errancia y no con la Ley. Este descubrimiento de la alteridad es, entonces, paradójico, aunque él mismo se salve.

La cuestión del sujeto también se acaba al final de la película. En efecto, durante la mayor parte de la película. El Carnicero habla (de él) en tercera persona, es decir, de forma impersonal, mientras que, en su último monólogo, domina la primera persona del singular, se personaliza como padre $^{12}$ y se convierte en sujeto. El "yo" ya no es otro.

Si El Carnicero no tiene nombre, Cynthia no tiene palabras, es callada, muda, sin voz, sin lenguaje. Pero Noé invierte la situación: durante la última escena, es Cynthia quien lleva a cabo el acto. Va a los brazos de su padre; ¿también está sola contra todos? La tragedia individual y social del padre comenzó su repetición con el internamiento de Cynthia.

$\mathrm{El}$ acto que Cynthia realiza puede resumirse mediante una cita de Christian Hoffmann (2004): ese acto sería 
"un pedido de amor, de reconocimiento del ser sobre un fondo de desesperación" (p. 19).

Giro inesperado de Gaspar Noé. El amor "salva”. En ese universo cerrado sobre sí mismo, la hija se convierte en la mujer, y la mujer en el amor. Tras mil errancias incestuosas, ligadas a la promiscuidad con una joven adolescente muda, el "héroe" descubre que siente por ella una ternura, un amor que, en cierto modo, trasciende todo el relato trágico y desesperado. Una luz de esperanza aparece: "solo contra todos" se transforma en "solos contra todos". Jugada maestra de Gaspar Noé: del sufrimiento insondable, de la soledad innombrable, de lo irreversible, surge una luz de esperanza, como una resurrección del sentimiento amoroso, un renacimiento de la ternura infinita. Situación imposible, impensable, innombrable y, en cierto modo, irrepresentable. Este hombre, Solo contra todos, ama a su hija como a una mujer. Quiere convertirla en mujer. Esa hija-mujer, siempre silenciosa, se acerca a él. Un horizonte aparece: después de toda una película confinada, mundo cerrado, se ve una calle, niños que juegan, la esperanza renace.

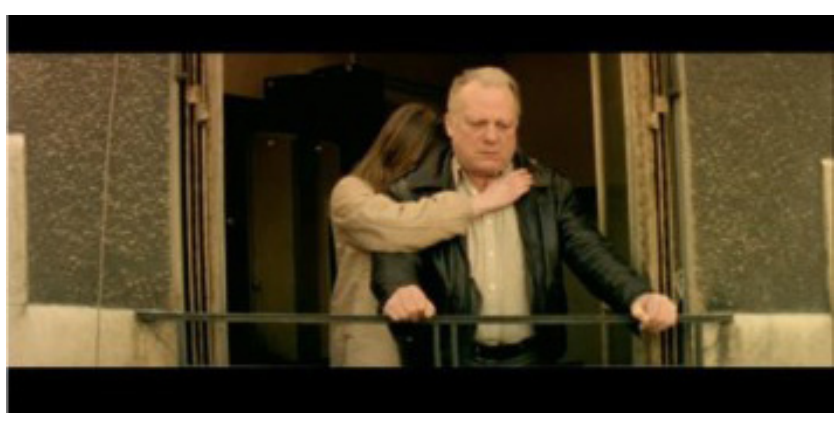

Cynthia va a los brazos de su padre, Solo contra todos, Noé

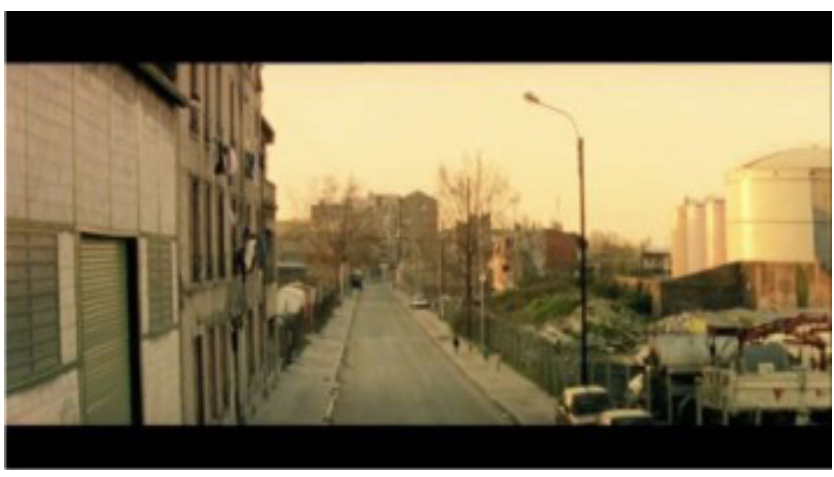

Último plano de la película, niños que juegan, Solo contra todos, Noé

\section{Referencias}

Agamben, G. (2008). Qu'est-ce que le contemporain ? París: Rivages poche/Petite Bibliothèque.

Aumont, J. (1999). L'analyse des films. París: Nathan [trad. esp: (2009). Análisis del film, traducción de Carlos Losilla. Barcelona: Paidós].

Bourdieu, P. (1992). La misère du monde. París: Seuil [trad. esp: (1999). La miseria del mundo, traducción de Horacio Pons. Buenos Aires: Fondo de Cultura Económica].

Camus, A. (2005). L'étranger. París: Folio [trad. esp.: (2003). El extranjero, traducción de José Ángel Valente. Madrid: Alianza Editorial].

Castel, R. (2009). Les métamorphoses de la question sociale. París : Fayard [trad. esp.: (2004). Las metamorfosis de la cuestión social. Una crónica del salariado, traducción de Jorge Piatigorsky. Buenos Aires: Paidós].

Chioua, B., Cassel, V. (productores) y Noé, G. (director). (2002). Irreversible [cinta cinematográfica]. Francia: Les Cinémas de la Zone.

Debord, G. (1967). La société du spectacle. París: Folio Gallimard [trad. esp.: (2008). La sociedad del espectáculo, traducción de F. Alegre. Buenos Aires: La marca].

Delbosc, O., Maraval, V., Missonnier, M., Noé, G. (productores) y Noé, G. (director). (2009). Enter the Void [cinta cinmatográfica]. Francia: Film France.

Douville, O. (dir.). Clinique psychanalytique de l'exclusion. París: Dunod.

Ferenczi, S. (2006). Le Traumatisme. París: Payot.

Freud, S. (1979). Malaise dans la culture. Paris : PUF [trad. esp.: (2010). El malestar en la cultura y otros ensayos, traducción de Ramón Rey Ardid y Luis López Ballesteros y de Torres. Madrid: Alianza].

Furtos, J. (2009). De la Précarité à l'auto-exclusion. París: Editions Rue d’Ulm.

Green, A. (2007). Narcissisme de vie, narcissisme de mort. París: Minuit [trad. esp.: (1986). Narcisismo de vida, narcisismo de muerte. Buenos Aires: Amorrortu].

Hachet, A. (2015). «Le passage à l'acte adolescent. Une tentative ratée de production du sujet ». En Recherches en psychanalyse, 20(2).

Hoffmann, C. (2004). L'agir adolescent. Toulouse: Erès. 
Jankélévitch, V. (2011) Les vertus et l'amour, Tome I, Traité des vertus II. París: Flammarion.

Kargl, G., Reitinger-Laska, J. (productores) y Kargl, G. (director). (1983). Angst [cinta cinematográfica]. Austria: Gerald Kargl.

Lacan J. (1966). Écrits, París: Le Seuil [trad. esp.: (2009) Escritos, traducción de Tomás Segovia, México: Siglo XXI].

Legrendre, P. (1995). La fabrique de l’homme occidental. París: Mille et une nuits/Arte éditions [trad. esp.: (2008). La fábrica del hombre occidental, traducido por Irene Agoff. Buenos Aires: Amorrortu].

Levi, P. (1990). Si C’est un Homme, trad. Martine Schruoffeneger. París: Julliard, coll. Pocket [trad. esp.: (2005). Si esto es un hombre. Barcelona: Muchnik].

Maraval, V., Chioua, B., Teixeira, R., Noé, G., Weil, E. (productores) y Noé, G. (director). Love [cinta cinematográfica]. Francia: Wild Bunch.

Marx, K. y F. Engels (2014). L'idéologie allemande. París: Editions Sociales [trad. esp.: (2014). La ideología alemana, traducción de Wenceslao Roces. Madrid: Ediciones Akal]

Nietzsche, F. (1989). La Naissance de la tragédie. París: Folio Gallimard [trad. esp.: (2018). El nacimiento de la tragedia o Grecia y el pesimismo, traducción de Andrés Sánchez Pascual. Madrid: Alianza Editorial].

Nietzsche, F. (1995). Humain, trop humain. París: Le Livre de poche [trad. esp.: (1966). Obras completas I: Consideraciones intempestivas; Humano, demasiado humano, traducción de Eduardo Ovejero y Maury. Madrid: Aguilar].

Nietzsche, F. (1987) Par delà le bien et le mal. París: Folio Gallimard [trad. esp.: (2007). Más allá del bien y del mal: preludio de una filosofía del futuro, traducción de Andrés Sánchez Pascual. Madrid: Alianza Editorial].

Noé, G. (productor y director). (1991). Carne [cinta cinematográfica]. Francia: Les Cinémas de la Zone.

Noé, G. (productor y director). (1998). Solo contra todos [cinta cinematográfica]. Francia: Les Cinémas de la Zone.

Noé, G. (2014). “Carne, Seul contre tous”. En L'avant-scène cinéma, 609.

Rimbaud, A, (2005). Poésies .París: Hatier [(2003). Poesía completa, traducción de J. F. Vidal-Jover. Barcelona: Ediciones 29].

Sublon, R. (dir.) (2016). Cinéphilies, l’intégrale. París: Association mon œil.

Tarkovski, A. (2004). Le Temps Scellé. París: Éditions de l'Étoile, Petite Bibliothèque des Cahiers du Cinéma.

Weil, E., Girard, A., Maraval, V. (productores) y Noé, G. (director). (2018). Clímax [cinta cinematográfica]. Francia: Rectangle Productions.

1 El Front National [Frente Nacional] (Rassemblement National desde 2018) es un partido político francés de extrema derecha. [N. de la T.]

2 Société nationale des chemins de fer français [Sociedad Nacional de Ferrorcarriles Franceses]. [N. de la T.]

3 El proyecto de ley Devaquet, presentado por Alain Devaquet en 1986 durante el segundo gobierno de Jacques Chirac, fue un proyecto de ley de reforma de las universidades francesas. [N. de la T.]

4 El apellido significa “equino” en francés. [N. de la T.]

5 En castellano, también “prójimo” o “semejante”. [N. de la T.]

6 Traducido literalmente del francés Enculé de ta race, insulto que reviste un carácter racista y homofóbico. [N. de la T.]

$7 \quad$ El té de menta es una bebida típica de los países árabes. [N. de la T.]

8 “France Chevaline" es el nombre del matadero al que El Carnicero va a buscar trabajo. [N. de la T.]

9 Rimbaud, A, (2005). “Les Poètes de sept ans. Lettre à Paul Demeny du 10 Juin 1871”. En Poésies. París: Hatier [(2003). "Los poetas de siete años". En Poesía completa, traducción de J. F. Vidal-Jover. Barcelona: Ediciones 29]. La traducción de los versos fue tomada de la edición en castellano mencionada aquí arriba. [N. de la T.]

10 «Con El espejo empecé a comprender que hacer una película, si uno toma su profesión en serio, no es solo una etapa en una carrera, sino un acto que determina todo un destino. Por primera vez, me animé a hablar con los medios del cine, directa y espontáneamente, de aquello que más significaba para mí, de lo más sagrado que había en mí». Tarkovski, A. (2004). Le Temps Scellé. París: Éditions de l’Étoile, Petite Bibliothèque des Cahiers du Cinéma.

11 En francés, hay un juego de palabras entre "contre tous" [contra todos] y "tout contre” [muy cerca de]. [N. de la T.]

12 «Père-sonnalise» en francés. Juego de palabras fonético que une las palabras père [padre] y personnaliser [personalizar]. [N. de la T.] 